\title{
高职“四学段循序渐进”的学做一体化人才培养方案建设 ——船舶电气工程专业为例
}

何 琪 徐鹏 林型平

浙江国际海运职业技术学院

DOI:10.32629/mef.v1i1.5

[摘 要] 要高质量的完成高职院校专业人才培养的目标, 确定一个合适的人才培养模式比较重要, 本文结合专业的实际 情况, 制定了一种“四学段循序渐进”的人才培养模式, 阐述了这种人才培养模式的基本内容, 在实践中体现的成效, 能验 证符合高职学生的专业技能学习和提升。

[关键词] 高职; 四段递进; 教学做一体

\section{1. 前 言}

高职学校的专业人才培养模式确定是专业人才培养 的重要环节, 要建设一个符合高职学生成才和专业学习 有效的目标, 制定出一个符合高职学生学习和提升能力 的专业人才培养模式在人才培养体系中也是尤为关键, 我校经过多年的实践, 在专业教学实施过程中不断总结, 得出了一个种符合现代高职教育规律的人才培养模式, 尤其是对于船舶电气工程技术这类实践要求比较高的专 业来说, 实施“四学段循序渐进”更能提升学生的专业学习 效率,完成专业人才培养目标。

\section{2. “四学段循序渐进”的人才培养模式}

\section{1 人才培养目标}

船舶电气工程技术专业培养思想政治坚定、德技并 修、全面发展, 适应船舶修造企业、船舶电气设备(配件)企 业、船舶航运企业与工业电气生产加工企业第一线需要
的, 具有良好职业道德和敬业精神, 掌握从事 (电气生产制 造、生产管理, 电气设备装置安装、调试与维护实际工作职 业岗位或岗位群) 实际工作的基础知识和技术技能, 具有 职业生涯发展基础, 具有较好的社会责任感、创新精神、实 践能力的德、智、体、美等方面全面发展的, 面向修造船, 船 舶电气设备, 工业电气生产领域的高素质劳动者和技术技 能人才。

\section{2 人才培养模式内容}

船舶电气工程专业 “四学段循序渐进” 的工学结合人 才培养模式, 船舶电气工程技术专业依托舟山船舶修造及 船舶电气设备生产企业, 以船舶电气生产、船舶电气设备 制造职业岗位能力要求为依据, 以企业典型船舶电气设备 生产的真实工作为基础, 根据企业生产流程基本一致的特 点和典型工作任务实施环境的要求, 将专业人才分“学校 ( I 学段)一学校 (II 学段)一学校( III 学段)一企业(IV 学段)”
相关从业人员等 5000 余人, 社会服务成效显著。2013年, 助 产专业被评为院级重点专业; 2016 年山东省职业院校第一 届助产技能大赛获得团体三等奖, 两名同学分获三等奖, 两名指导教师获 “优秀指导教师” 称号; 2017年助产专业作 为其中之一专业的医药护养专业群被批准为山东省品牌 专业群。

\section{五、主要改革成果和实践效果}

研究成果中有多篇、多部高水平论文及教材, 部分研 究内容已编进教材, 对助产专业学生的专业学习起到了 良好的促进作用。通过调研, 我校该专业就业率一直保持 在 $98 \%$ 以, 毕业生受到用人单位的好评, 效果明显。教学 成果还在多家单位推广应用, 对专业人才培养发挥了积极 促进作用。

\section{[参考文献]}

[1]何秋兰, 徐占春. 梳理中国微课研究现状 [J]. 中国 教育网络, 2014,(2).74-76

[2]陈庆文, 黄燕玲. 微课及其在教师专业发展中的运 用[J].教学与管理, 2014,(36).145-147.

[3]王亚盛, 从迎九. 微课程设计制作与翻转课堂教学 应用[M].北京: 机械工业出版社,2016.

[4]梁乐明, 曹俏俏, 张宝辉. 微课程设计模式研究一 基于国内外微课程的对比分析 [J]. 开放教育研究,2013,19 (1).65-73.

作者简介: 于蕾(1981.06-), 女, 汉族, 山东滕州人, 本科, 副教授, 研究方向:妇产科。 
四个学段进行培养。第 I 学段,学生主要在学校进行基本 知识准备, 训练基本技能; 第 II 学段, 学生在学校学习专业 知识, 提升专业技能; 第 III学段, 学生在校专项实践演练, 提高专业能力; 第 $\mathbb{V}$ 学段, 学生在企业顶岗实习, 独立完成 企业作业计划, 培养职业综合能力, 提升职业综合素质。如 下图所示

\section{3. 学做一体的人才培养模式实现}

3.1 课程体系与教学内容改革

(1)建立以职业活动为导向、实践技能为核心、项目 驱动为载体的 “双证融通”课程体系。在两年建设期内, 引 人行业企业标准开发专业课程, 建设5 门优质专业核心课 程, 校企共同对职业岗位的任务、工作项目进行了梳理, 明 确了各工作项目的知识和技能, 结合维修电工、船舶电工 职业技能鉴定标准, 制订了专业人才培养方案, 构建了“双 证融通”课程体系, 从工作任务和能力结构分析着手, 突出 提高选修学分, 确保实践教学课时比例, 。学生通过 3 年 的学习和训练, 毕业前参加维修电工 (中级) 或船舶电 工 (中级) 考试, 在取得高职毕业证书的同时, 获得职业 资格证书。

(2)为满足学生实践性教学的需要, 在校重点专业建 设期内将本专业的核心课程进行理实一体化和项目化教 学改革。

(3)在课堂教学改革创新方面, 以“做中教才是真的 教、做中学才是真的学”为指引, 推进“学做合一”理论实践 相统一的课堂教学, 从而提高课堂教学效率。通过校企合 作建立船舶电气设备生产技术服务中心、校内项目化实训 基地、校外企业生产性实习基地, 实施多种形式的现场教 学, 丰富课堂形式和教学手段, 创新教学形态。与三峰电 气设备有限公司制定关于校企合作开发课程的协议, 效 地促进企业技术人员担任实践教学指导工作, 丰富实践 教学手段, 使学生在真实情境中学习和锻炼, 实现理论与 实践、课堂与车间、教学与生产的有机统一, 从而达到教学 内容与岗位工作任务的有效对接。通过 “学做合一”课堂教 学、生产性实训基地岗位技能训练、全企业化岗位实习、学 生创新创业实践等多层次的灵活教学途径, 实现工学结合 的教学要求。

(4)校企合作建设一批优质教材, 不断将企业生产实 际中的新知识、新技术、新工艺、新设备反映到教材中去; 课程教学案例及实训任务采用校内生产性实训车间及企 业的完成电气控制及操作, 并将电气设备接线工任务作
为学生作业、教材作为学生生产性实训的任务书和工艺文 件; 教材采用多种立体化表现形式, 充分、直观展示零件加 工过程,提高教材的实用性、针对性和灵活性。

\section{2 “双师”队伍建设及管理体制与机制创新}

(1)着力培养 1 名专业带头人, 通过专项培训进修、承 担科技项目、下企业兼职锻炼、参与企业技术改造与创新、 发明获取专利等途径, 提升其教学、科研水平及课程开发、 课程体系建设、教学团队管理能力, 增加企业一线工作经 历, 熟悉行业企业最新技术动态。

(2)注重专业骨干教师的培养, 通过学位学历提升、 职业教育能力培训、企业实践、参与企业技术服务等, 提升 专业骨干教师的专业能力, 尤其是课程开发能力和技能服 务能力。专业师资队伍的“双师”素质比例达 $80 \%$ 以上。

(3)密切与企业的合作, 从企业聘请既有理论水平又 有实践经验的工程技术人员 6 名, 担任本专业的兼职教师, 重点承担本专业实践技能的教学工作, 同时参与课程标准 制订与实践教学项目设计, 参与工学结合教材和教学资源 开发。通过建设使专兼职教师比例达到 $1: 1$, 建立由企业专 家、工程技术人员组成的兼职教师资源库 (库内人员达 25 名以上), 主要负责校内生产性实训项目制定和指导、顶岗 实习项目拟订和指导等。

\section{3 教学模式改革}

(1)开展船舶电气工程技术专业人才需求市场调查: 以舟山市内176家船舶企业为主, 面向浙江省的船舶制造 及电气设备生产企业, 开展人才需求与岗位能力要求调 研, 获取船舶电气工程技术专业人才需求的基本资料。

(2)广泛吸纳更多船舶电气行业专家和企业技术能手 进人专业建设委员会, 共同确立人才培养定位、岗位技能 标准和素质要求、培养体系, 充分发挥行业、企业的作用, 共同制订和完善人才培养方案。

(3) 与地方大型企业深度合作, 探索建立校企业合作 的长效机制。

3.4 学生学业评价体系改革

本专业以提高学生就业竞争力和可持续发展能力为 重点, 以大学生素质拓展计划为统揽, 针对高职学生特点 开展了丰富多彩的素质教育活动, 全面实施素质教育。

通过建立学生机电研发兴趣小组, 培养学生独立思 考、勇于创新、爱岗敬业的职业道德品质和社会责任意识。 通过举办大学生技能竞赛、社会实践与志愿服务活动、职 业技能大赛等活动, 全面提高大学生综合素质。专业综合 
实习与就业岗位相对应, 使用人单位对本专业毕业生综合 素质、专业知识、职业能力、职业修养、实际动手能力方面 的满意率提高到 $90 \%$ 以上。

\section{5 教学实验实训条件建设}

(1)校内实训建设。在船舶实训中心已经建了相对独 立的船舶电气实训场所, 包括维修电工实训室、船舶电气 设备排故实训室、PLC实训室、微机实训室、船舶电工工艺 实训室、电机与电力拖动实训室和船电 $\mathrm{CAD} / \mathrm{CAM}$ 实训室。 随着专业的发展在船舶电气排故实训室、电气综合实训 室、电机与电力拖动控制实训室、船舶自动化实训室和船 舶生产设计实训室需要扩建或新建。校企合作, 共建具有 先进性、生产性和可持续性的开放型、区域共享型实训基 地。

(2)校外实训基地建设。以船舶行业为依托,在原有校 外实训基地的基础上, 分别在2015 2018年共增10个校外 实训基地, 满足学生在企业的工学交替和顶岗实习的需 要, 使学生在第六学期 $100 \%$ 能参与校外顶岗实习。

(3) 实训管理制度及配套建设。加快实训教学教材、仿 真软件、教学课件、网络资源等软件建设与培训包的开发, 完善实训管理制度和顶岗实习管理制度。成立以专业主 任为组长的顶岗实习指导小组, 负责与企业、行业的联系, 拓宽学生顶岗实习和就业岗位的渠道, 落实学生顶岗实习 岗位; 规范学生顶岗实习过程跟踪与管理。

\section{6 教学质量保障体系建设}

以学校质量管理体系体系为抓手, 加强专业教学的制 度建设, 重点建立和完善实践教学与管理标准, 如: 顶岗实 习手册、实习指导教师管理规范等。借鉴企业“7 5 管理”的 理念与方法, 加强校内实训室管理, 完善各实训室管理制 度与标识。注重教学质量评价和过程监控, 建立与专业改 革相适应的教学规范、管理制度和评价机制, 确保专业人 才培养质量。建立教学信息收集和教学质量反馈制度, 为 专业改革提供指导, 并逐步形成企业和船舶电气技术专业 的共同评价机制; 建立教学质量监控机制, 包括学校教学
督导制度、企业教学质量监控、学院教学质量检查。建立和 完善教学标准, 包括教师评价和考核标准、课程教学和考 核标准、学生校内实训和校外实习质量评价标准等。改革 考试方法, 由过去对单一要素考核过渡到对整体质量要素 考核, 以增强学生质量、成本和效率意识; 强调学生“真刀 真枪” 的岗位训练, 有效地培养学生的职业素质与实际工 作能力。

\section{4. 成效}

依托船舶行业,地方大型集团有限公司、企业、工厂等 深度合作,围绕船舶制造、维修岗位的核心技能, 深化“四 学段循序渐进”工学结合的人才培养模式, 以企业典型船 舶电气设备生产的真实工作为基础, 根据企业生产流程基 本一致的特点和典型工作任务实施环境的要求。

建立工学结合、以职业活动为导向、以素质为基础、突 出能力目标的课程体系逐步按计划进行基于职业素质的 基础课、基于工作过程的专业课、基于专业技能的实训课 课程内容改革。根据课程内容和学生特点, 合理设计教学 方法和教学评价, 积极探索实践工学交替、任务驱动、项目 导向、课堂与实习地点一体化的教学模式, 通过精品资源 库的建设来带动专业课程的建设。邀请更多行业专家和 企业技术能手共同参与核心课程的建设工作, 按照项目驱 动原则,改革和建设核心课程。

\section{[参考文献]}

$[1]$ 傅伟.高职教育人才培养方案的研究与实践 [J]. 中国成人教育, 2008,(9).106-107.

[2]杨红霞. 改革人才培养模式提高人才培养质量[J]. 中国高教研究,2014,(10).56.

[3]张志伟, 赵峰, 刘志㑆. 电子信息工程专业人才培 养模式研究与实践一以陕西理工学院为例 [J]. 黑龙江教 育: 高教研究与评估,2016,(4).88.

作者简介: 何琪(1980.03-) 男, 汉族, 浙江舟山人, 硕士, 副 教授, 研究方向: 船舶电气自动化。 